\title{
DEGRADATION OF ACID VIOLET 7 AND REACTIVE BLACK 5 IN WATER BY ELECTRO-FENTON AND PHOTO ELECTRO-FENTON BY
}

\author{
R. SALAZAR*\& M. S. URETA-ZAÑARTU \\ a Departamento de Ciencias del Ambiente, Facultad de Química y Biología, Universidad de Santiago de Chile, USACh, \\ Casilla 40, correo 33, Santiago (Chile)
}

(Received: May 20, 2011 - Accepted: September 20, 2011)

\begin{abstract}
The mineralization of solutions containing azo dyes Acid Violet 7 (AV7) and Reactive Black 5 (RB5) in aqueous solutions using electro-Fenton (EF) and Photo electro-Fenton (PEF) methods were determined. The electrochemical system includes a glassy carbon mesh electrode (cathode) with a concentric outer steel mesh as anode. The optimized parameters were: $0.01 \mathrm{mM}$ of $\mathrm{Fe}^{2+}$ ions, and $250 \mathrm{~mA}$ of applied current at $\mathrm{pH} 3$. All experiments were made at $35^{\circ} \mathrm{C}$. The degradation was evaluated by color removal and total organic carbon (TOC) decay for solutions of $250 \mathrm{mg} \mathrm{L}^{-1}$ of both cases. The results indicate that the system achieves a degradation efficiency for both dyes proposed, being observed a quickly decolorization of the solutions and the complete transformation of organic compounds to carbon dioxide. The efficiency process and decoloration kinetic constant were evaluated. Generated carboxylic acids such oxalic, oxamic, citric and maleic were found by ion exclusion chromatography. A comparison of the electrochemical system with respect to Fenton`s and Photo-Fenton reaction was also performed.
\end{abstract}

Keywords: Azo dye oxidation, electro-Fenton, Photo electro-Fenton, Hydroxyl radical, Mineralization.

\section{INTRODUCTION}

In Chile, the treatment of textile wastewaters is governed by the Chilean standard': DS MOP 609 (2005), which is only focused on four parameters: solid waste (luff), temperature, foam and $\mathrm{pH}$. The final color of the water is not considered. Color in water is a consequence of small quantities of dyes, interfering with transmissions of sunlight into natural streams. Azo dyes and their intermediate products, such as aromatic amines, are toxic to aquatic life; carcinogenic and mutagenic to humans $\mathbf{s}^{2,3}$. For these reasons, dyes must be removed from textile wastewaters before being discharged.

In the last decade, the electrochemical technology has been largely developed as an alternative use in the remediation of organic pollutants in wastewaters, due to environmental compatibility and high energy efficiency. Electrochemical procedures as Electro-Coagulation (EC) 4,5 $^{\text {, Electrochemical }}$ Oxidation (EO) ${ }^{6,7}$, Electro-Fenton (EF) and photoassisted systems like Photo Electro-Fenton (PEF) ${ }^{8-910}$ and Photoelectrocatalysis ${ }^{11}$ have been classified as electrochemical advanced oxidation processes $(\mathrm{EAOPs})^{12,13}$.

By EF and PEF the dyes are degraded by the ${ }^{\circ} \mathrm{OH}$ radicals generated by Fenton's reaction ${ }^{14-16}$. This radical is the second strongest oxidant known after fluorine, with high standard potential $\left(\mathrm{E}^{0}=2.80 \mathrm{~V} v s\right.$. SHE) that ensures its fast reaction with most organics, giving dehydrogenated or hydroxylated derivatives up to complete conversion into $\mathrm{CO}_{2}$. The generation of ${ }^{\circ} \mathrm{OH}$ occurs from the reaction between $\mathrm{H}_{2} \mathrm{O}_{2}$ activated in acidic effluents with $\mathrm{Fe}^{2+}$ ion as catalyst (Fenton's reagent). It has been reported that $\mathrm{H}_{2} \mathrm{O}_{2}$ can be accumulated in aqueous medium from the cathodic reduction of dissolved $\mathrm{O}_{2}$ gas $^{17,18}$ at carbonaceous electrodes with high surface area ${ }^{19-24}$. The corresponding twoelectron reaction with $\mathrm{E}^{0}=0.68 \mathrm{~V} v s$. SHE can be written as follows:

$\mathrm{O}_{2}(\mathrm{~g})+2 \mathrm{H}^{+}+2 \mathrm{e}^{-} \rightarrow \quad \mathrm{H}_{2} \mathrm{O}_{2}$

which takes place more easily than the four-electron reduction of oxygen gas to water $\left(\mathrm{E}^{0}=1.23 \mathrm{~V} v\right.$ s. SHE $)$.

The EF treatment of wastewaters involves the continuous generation of $\mathrm{H}_{2} \mathrm{O}_{2}$ from dissolved $\mathrm{O}_{2}$ directly injected as pure gas or air, which is efficiently reduced at different cathode ${ }^{22-25}$ (reticulated vitreous carbon, carbon felt, graphite-polytetrafluoroethylene (PTFE), and carbon-PTFE $\mathrm{O}_{2}$-diffusion, etc.) via reaction (1). When a small catalytic quantity of $\mathrm{Fe}^{2+}$ is added to the acidic contaminated solution, $\mathrm{Fe}^{3+}$ and $\bullet{ }^{\bullet} \mathrm{OH}$ are generated according to the classical Fenton's reaction (2) with a second order rate constant $\left(\mathrm{k}_{2}\right)$ of $63 \mathrm{M}^{-1} \mathrm{~s}^{-118}$.

$$
\mathrm{Fe}^{2+}+\mathrm{H}_{2} \mathrm{O}_{2} \rightarrow \mathrm{Fe}^{3+}+\cdot \mathrm{OH}+\mathrm{OH}^{-}
$$

Reaction (2) can be propagated indefinitely due to the reversible behavior of the $\mathrm{Fe}^{3+} / \mathrm{Fe}^{2+}$ couple.

On the other hand, in photoassisted EAOPs based on the photochemical and/or photocatalytic action of UV irradiation, the intensity and wavelength of the incident light play a significant role on the destruction rate of organic pollutants. The PEF method consists in the simultaneous use of electrogenerated $\mathrm{H}_{2} \mathrm{O}_{2}$ in the presence of $\mathrm{Fe}^{2+}$ (EF conditions) and UV illumination of the solution to mineralize the pollutants. The action of this irradiation is complex and can be described by: (a) the increase in the production of hydroxyl radical from photoreduction of $\mathrm{Fe}(\mathrm{OH})^{2+}$ and (b) the predominant $\mathrm{Fe}^{3+}$ species in acid medium and/or the photolysis of complexes of Fe(III) with generated carboxylic acids, as shown Eq. (3) and (4), respectively.

$$
\begin{aligned}
& \mathrm{Fe}(\mathrm{OH})^{2+}+\mathrm{h} v \rightarrow \mathrm{Fe}^{2+}+\cdot \mathrm{OH} \\
& 2 \mathrm{Fe}\left(\mathrm{C}_{2} \mathrm{O}_{4}\right)_{\mathrm{n}}(3-2 \mathrm{n})+\mathrm{h} v \rightarrow 2 \mathrm{Fe}^{2+}+(2 \mathrm{n}-1) \mathrm{C}_{2} \mathrm{O}_{4}^{2-}+\mathrm{CO}_{2}
\end{aligned}
$$

The enhancement of the degradation rate of this process respect to the EF (when the solution is irradiated) is well recognized ${ }^{26,27}$.

Among the dyes commonly used in Chile, we can find the Acid Violet 7 (AV7) and Reactive Black 5 (RB5) (Fig. 1). Both dyes belong to the group of azo compounds. In the literature, is possible found different no electrochemical methods used for the degradation of AV7 and RB5 by Fenton or Fenton like reaction and photochemical treatment ${ }^{28-32}$. However, under these methods, the mineralization does not exceed $80 \%$ even in long times of reaction, they use low dye concentrations and in some cases they establish a direct relationship between mineralization and decolorization.

In the present work, the indirect oxidation of azo dyes AV7 and RB5 using $\mathrm{EF}$ and PEF procedures is shown. Determinate the best experimental conditions to destroy completely these compounds in aqueous solution and compare the efficiency of both methods respect classic Fenton reaction. Intermediates carboxylic acids were detected by ion exclusion chromatography. Efficiency of mineralization and kinetic analysis were evaluated for each process.

\section{MATERIALS AND METHODS}

\section{Chemical and reagents}

Chemicals, Acid Violet 7 (AV7, dye content $40 \%$ Color Index Number 18055 ) and Reactive Black 5 (RB5, dye content $55 \%$ Color Index Number 305462) were purchased at Aldrich and were used as received. $\mathrm{Na}_{2} \mathrm{SO}_{4}$, $\mathrm{FeSO}_{4} * 7 \mathrm{H}_{2} \mathrm{O}, \mathrm{H}_{2} \mathrm{SO}_{4}, \mathrm{H}_{2} \mathrm{O}_{2}$ and $\mathrm{NaOH}$ (Merck p.a) were also used as received. Double distilled water (conductivity $<6 \mathrm{mS}$ ) was used to prepare all aqueous solutions. Dye solutions were prepared by dissolving $25 \mathrm{mg}$ of AV7 and/or RB5 in $100 \mathrm{~mL}$ of $0.1 \mathrm{M} \mathrm{Na}_{2} \mathrm{SO}_{4}$, used as supporting electrolyte. Solution $\mathrm{pH}$ was adjusted to the desired value by addition of drops of $\mathrm{H}_{2} \mathrm{SO}_{4}$ or $\mathrm{NaOH}$ concentrated solutions. $\mathrm{pH}$ was measured using an EXTECH Instrument $321990 \mathrm{pH}-$ meter.

Apparatus and analytical procedures 
The galvanostatic experiments were performed using a one compartment cell of $100 \mathrm{~mL}$ with a WENKING POS 75 potentioscan (Resistance $1 \mathrm{~W}$ ). The system includes a heat exchanger and a magnetic stirrer. A glassy carbon mesh electrode ( $\mathrm{CH}$ Instrument) was used as a cathode and a concentric outer steel mesh as an anode. $\mathrm{O}_{2}$ gas $(99.99 \%$, Indura S.A) was bubbled in the solution during the electrolysis. The electrolytic media was $0.1 \mathrm{M} \mathrm{Na}_{2} \mathrm{SO}_{4}$. All experiments were made at $35^{\circ} \mathrm{C}$ in concordance with Boyle et al ${ }^{33}$.

Color removal was monitored by spectrophotometric measurements evaluating the absorbance decrease in the UV-Vis spectra, using a Cary $1 \mathrm{E}$ Varian spectrophotometer. The percentage of color removal during the treatment of dyes wastewaters was determined by the expression:

$$
\text { Color removal }(\%)=\frac{\mathrm{ABS}_{0}^{\mathrm{M}}-\mathrm{ABS}_{\tau}^{\mathrm{M}}}{\mathrm{ABS}_{0}^{\mathrm{M}}} \times 100
$$

where $\mathrm{ABS}_{0}{ }^{\mathrm{M}}$ and $\mathrm{ABS}_{\mathrm{t}}^{\mathrm{M}}$ are the average absorbances at time 0 and $\mathrm{t}$, respectively, at the maximum visible wavelength of the wastewater $\left(1_{\max }: 517\right.$ $\mathrm{nm}$ for AV7 and $594 \mathrm{~nm}$ for RB5, Fig. 1).
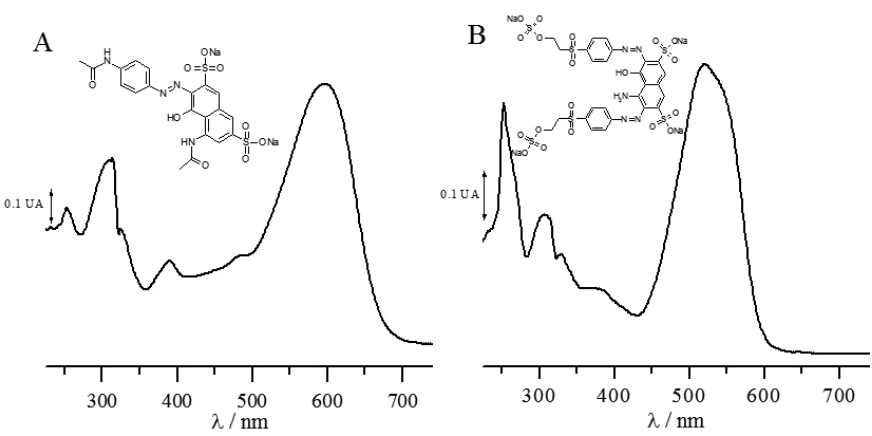

Figure 1. Structures and UV-Vis spectra of Acid Violet 7 (A) and Reactive Black 5 (B).

The mineralization was followed from decay of total organic carbon (TOC) using a Teledyne Tekmar Phoenix 8000 and the percentage of TOC decay was calculated from the equation:

$$
\text { TOC decay }(\%)=\frac{\Delta T O C_{t}}{T O C_{0}} \times 100
$$

where $\triangle \mathrm{TOC}_{\mathrm{t}}$ is the removal organic carbon $\left(\Delta \mathrm{TOC}_{\mathrm{t}}=\left(\mathrm{TOC}_{0}-\mathrm{TOC}_{\mathrm{t}}\right)\right.$ in $\mathrm{mg} \mathrm{L}{ }^{-1}$ ) at electrolysis time $\mathrm{t}$, and $\mathrm{TOC}_{0}$ is the initial value before treatment.

The mineralization current efficiency (MCE), was estimated by TOC decay using the expression ${ }^{8}$

$$
\operatorname{MCE}(\%)=\frac{\mathrm{nF} V_{s} \Delta(\text { TOC })_{\exp }}{4.32 \times 10^{7} \mathrm{mIt}} \times 100
$$

where $n$ is the number of electrons consumed in the mineralization reaction by mol of VA7 or RN5, $F$ is the Faraday constant $\left(96,487 \mathrm{C} \mathrm{mol}^{-1}\right), \mathrm{V}_{\mathrm{s}}$ is the solution volume (L), D(TOC) $)_{\exp }$ is the experimental TOC decay $\left(\mathrm{mg} \mathrm{L}^{-1}\right), 4.32$ $\times 10^{7}$ is a numerical factor for unit homogenization $\left(3600 \mathrm{~s} \mathrm{~h}^{-1} \times 12.000 \mathrm{mg}\right.$ of $\left.\mathrm{C} \mathrm{mol}^{-1}\right), m$ is the number of carbon atoms in dye molecule $(\mathrm{m}=20$ and 26 for AV7 and RB5, respectively), $I$ is the applied current (A) and $t$ is the electrolysis time (h). The n-value for AV7 was taken equal to 112 considering the overall mineralization reaction of AV7 leading to carbon dioxide, sulfuric and nitric acids, according to: $\underset{\text { (8) }}{\mathrm{C}_{20} \mathrm{H}_{18} \mathrm{O}_{9} \mathrm{~S}_{2} \mathrm{~N}_{4}+51 \mathrm{H}_{2} \mathrm{O} \rightarrow 20 \mathrm{CO}_{2}+112 \mathrm{H}^{+}+112 \mathrm{e}^{-}+2 \mathrm{H}_{2} \mathrm{SO}_{4}+4 \mathrm{HNO}_{3}}$

Similarly, 152 electrons were taken for RB5 (transforming sulfur and nitrogen in sulfuric and nitric acids) ${ }^{16}$ according to the reaction:

\footnotetext{
$\mathrm{C}_{26} \mathrm{H}_{21} \mathrm{O}_{19} \mathrm{~S}_{6} \mathrm{~N}_{5} \mathrm{Na}_{4}+72 \mathrm{H}_{2} \mathrm{O} \rightarrow 26 \mathrm{CO}_{2}+152 \mathrm{H}^{+}+152 \mathrm{e}^{-}+4 \mathrm{H}_{2} \mathrm{SO}_{4}+5$ $\mathrm{HNO}_{3}+2 \mathrm{Na}_{2} \mathrm{SO}_{4}$

Samples extracted from electrolyzed solutions were filtered with 0.45 mm PTFE filters from Biofil and then analyzed in order to determine the concentration decay of each dye by HPLC and determine the presence of carboxylic acids by ion exclusion chromatography. The dyes concentration were followed by reversed-phase HPLC chromatography using a VWR Hitachi HPLC liquid chromatograph fitted with a Purospher Star RP-18 $5 \mathrm{~mm}, 250 \mathrm{~mm}$ x $4.6 \mathrm{~mm}$ (i.d.), column, at room temperature, and coupled with a VWR Hitachi L-2455 photodiode array detector, which was selected for each compound at the maximum wavelength of its UV-absorption band $(1=517 \mathrm{~nm}$ for AV7 and $1=594 \mathrm{~nm}$ for RB5). Different concentrations of dyes were prepared and evaluated in the chromatograph. Calibration curves for each dye showed the follow linear regressions:

$$
\begin{aligned}
& \text { Area }=0.36[\mathrm{RB} 5]+0.09 \\
& \text { Area }=0.43[\mathrm{VA} 7]+0.06
\end{aligned}
$$

Carboxylic acids were analyzed in a Waters HPLC chromatograph fitted with an Aminex HPX-87H, 300 x $7.8 \mathrm{~mm}$, column at $35^{\circ} \mathrm{C}$ from Bio-Rad and coupled with the Waters 996 photodiode array detector selected at $210 \mathrm{~nm}$. For all HPLC measurements, $25 \mu \mathrm{L}$ aliquots were injected into the chromatograph. A $70: 30(\mathrm{~V} / \mathrm{V})$ acetonitrile/acetate buffer $(\mathrm{pH} 4.0)$ mixture at $0.5 \mathrm{~cm}^{3} \mathrm{~min}^{-1}$ and $4.0 \mathrm{mmol} \mathrm{L}-1 \mathrm{H}_{2} \mathrm{SO}_{4}$ solution at $0.6 \mathrm{~cm}^{3} \mathrm{~min}^{-1}$ were used as mobile phase for reversed-phase and ion-exclusion HPLC, respectively.

Finally, a comparison with a classic Fenton's reaction was realized in similar condition to the electrochemical experiments. The concentration of $\mathrm{H}_{2} \mathrm{O}_{2}$ and $\mathrm{Fe}^{2+}$ were $1.0 \mathrm{mM}$ and $0.5 \mathrm{mM}$, respectively.

\section{RESULTS AND DISCUSSION}

\section{Electro-Fenton process}

The mineralization of AV7 and RB5 was studied by electro-Fenton process under different experimental conditions in order to investigate the influence of operative parameters $\left(\mathrm{Fe}^{2+}\right.$ concentration, applied current and $\left.\mathrm{pH}\right)$ on color removal (\%), TOC decay (\%) and mineralization current efficiency (MCE).

a) $\mathrm{Fe}^{2+}$ concentrations. Since a quick regeneration of the $\mathrm{Fe}^{2+}$ ions by reduction of $\mathrm{Fe}^{3+}$ at the cathode occurs in $\mathrm{EF}$ method, it is important to determine the minimum concentration need to obtain a high reaction rate for the dye degradation. Figure 2A shows the effect of $\mathrm{Fe}^{2+}$ concentration in the decolorization of AV7 solutions. In the absence of ferrous ions, after $60 \mathrm{~min}$ at $200 \mathrm{~mA}$ in $\mathrm{pH} 3$ (curve 1) $8-10 \%$ decolorization was reached. This base level of reaction in the absence of $\mathrm{Fe}^{2+}$ could be achieved to $\mathrm{O}_{2}$ reduction on the cathode, generating $\mathrm{H}_{2} \mathrm{O}_{2}$, which continues reacting at the cathode plus some anodic reaction of the dyes. In the presence of $\mathrm{Fe}^{2+}$ ions, decolorization of the solutions is observed even at low $\mathrm{Fe}^{2+}$ concentration. For example, at 30 minutes of electrolysis at $200 \mathrm{~mA}$ in $\mathrm{pH} 3$, the color removal was close to $40 \%$ for 0.01 and $0.05 \mathrm{mM} \mathrm{Fe}^{2+}$ (curve 2 and 3). At $0.1 \mathrm{mM} \mathrm{Fe}_{2} \mathrm{SO}_{4}$ (curve 4) the decolorization reaches the maximum values at short times $(90 \%$ at $30 \mathrm{~min}$ ). Similar results were observed at $0.5 \mathrm{mM} \mathrm{Fe}^{2+}$ (curve 5). On the other hand, in agreement with other authors ${ }^{9}$, at 1.0 and $2.0 \mathrm{mM}$ in $\mathrm{Fe}^{2+}$ further improvement in dye removal (curves 6 and 7) are not brought about, this phenomena could be related to a decrease of hydroxyl radical caused by an excess of ferrous ions. Parallel reactions could be occurring at low and high concentrations of $\mathrm{Fe}^{2+}$ ${ }^{35}$, the MCE did not exceed $30 \%$. Consequently $0.1 \mathrm{mM}$ of $\mathrm{Fe}^{2+}$ is selected as optimum value for further experiments.

b) Applied Current. As it is known, the electrical current is the measure of the reaction rate in an electrochemical reaction, and the maximum reaction rate is the diffusional control. In this sense, it is important to optimize the applied current in order to achieve a quickly decrease in color and mineralization to $\mathrm{CO}_{2}$ by applying the smallest possible current. That is, avoid forcing both the system and parallel reactions consuming part of the applied current. The influence of applied current on the degradation of both AV7 and RB5 dyes was studied in the range of $50-350 \mathrm{~mA}$ and the results are illustrated in Fig 2B for AV7. Two groups of curves depending on the applied current value were observed, being $200 \mathrm{~mA}$ the critical value (Fig. 2B). Considerable enhancement of the decolorization is observed for currents equal or higher than $250 \mathrm{~mA}$, specially at initial time, associated with high generation of $\mathrm{H}_{2} \mathrm{O}_{2}$ and the subsequent increase of hydroxyl radicals from Fenton's reactions. Finally, applied current of $250 \mathrm{~mA}$ were used in the following experiments. 

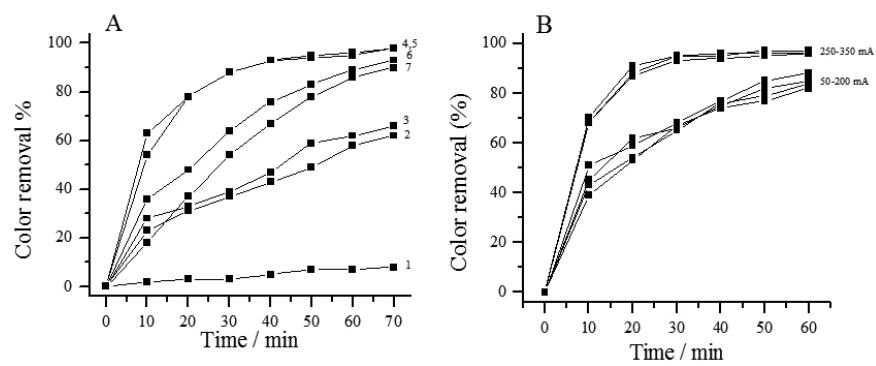

Figure 2. Color removal (\%) of $250 \mathrm{~g} \mathrm{~L}^{-1}$ of AV7 solutions in $0.1 \mathrm{M}$ $\mathrm{Na}_{2} \mathrm{SO}, \mathrm{pH} 3$ at $35^{\circ} \mathrm{C}$. (A) Influence of $\mathrm{Fe}^{2+}$ concentration. (1) $0.0 \mathrm{mM}$, (2) $0.01 \mathrm{mM}$, (3) $0.05 \mathrm{mM}$, (4) $0.1 \mathrm{mM}$, (5) $0.5 \mathrm{mM}$, (6) $1.0 \mathrm{mM}$ and (7) $5.0 \mathrm{mM}$. (B) Influence of applied current (between 50-350 mA) using a $0.5 \mathrm{mM}$ of $\mathrm{Fe}^{2+}$.

c) $\underline{\mathrm{pH}}$. A direct $\mathrm{pH}$ effect was observed for the electro-Fenton process in the oxidation of AV7 and RB5. The higher decolorization of the solutions was reached at $\mathrm{pH} 3$, as it is shown in Fig. 3 for $250 \mathrm{mg} \mathrm{L}^{-1}$ of RB5. These values are in agreement with the results of other authors ${ }^{\square}$, due to it is known that at $\mathrm{pH} 2.8$, the production of ${ }^{\bullet} \mathrm{OH}$ in homogeneous medium reaches a maximum in the Fenton's reaction. Thus, the initial $\mathrm{pH}$ of samples treated by EF in this work was always regulated to a value near 3.0 to ensure the fastest generation of homogeneous ${ }^{\bullet} \mathrm{OH}$.

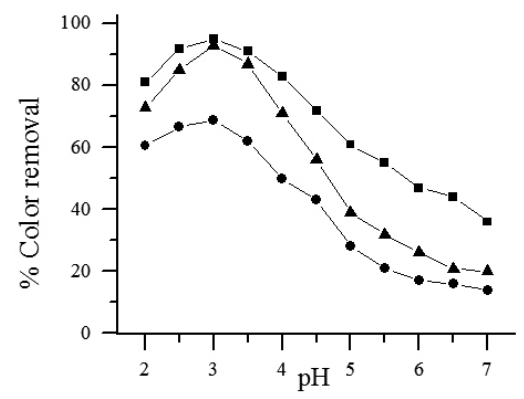

Figure 3. Effect of $\mathrm{pH}$ in the color removal (\%) of $250 \mathrm{gL}^{-1}$ of RB5 solution after $10 \mathrm{~min}(\bullet), 30 \mathrm{~min}(\boldsymbol{\Delta})$ and $60 \mathrm{~min}(\boldsymbol{\bullet})$ of electrolysis. Experimental conditions: $0.1 \mathrm{mM} \mathrm{Fe}{ }^{2+}, 250 \mathrm{~mA}$ applied current in $0.1 \mathrm{M} \mathrm{Na}_{2} \mathrm{SO}_{4}$ at $35^{\circ} \mathrm{C}$.

Figure 4 illustrates color removal (\%) (A) and TOC decay (\%) (B) of AV7 and RB5 (250 mg L-1) under the optimum parameters selected: $0.01 \mathrm{mM} \mathrm{Fe}^{2+}$ ions, $\mathrm{I}=250 \mathrm{~mA}, \mathrm{pH} 3$. As can be seen, the decolorization of both dyes solutions is quickly reached, exceeding $80 \%$ of color removal at $30 \mathrm{~min}$. After $60 \mathrm{~min}$ of electrolysis, the decolorization of the solutions is almost complete $(98 \%)$. During the electrolysis it was observed that together with the decolorization, the solution attained a clear-yellow color after 20-25 minutes, which was more intense for RB5 than for AV7. That coloration can be associated with the accumulation of highly conjugated aromatics by-products and small carboxylic acids $^{31}$. Note that at $30 \mathrm{~min}$ the TOC decay is very small in spite of the color removal is close to $80 \%$. In fact, Fig. 4B shows an induction time for TOC decay near to $20 \mathrm{~min}$.
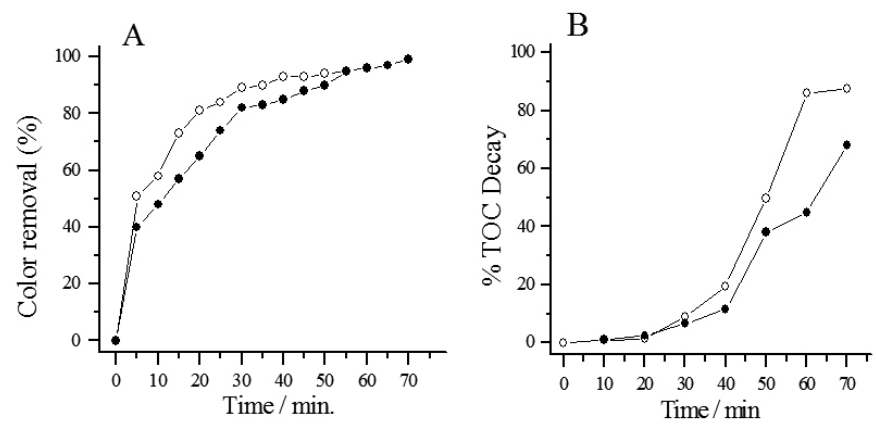

Figure 4. Degradation of AV7 (०) and RB5 (•) $\left(250 \mathrm{mg} \mathrm{L}^{-1}\right)$ by EF process. $0.01 \mathrm{mM} \mathrm{Fe} e^{2+}, 250 \mathrm{~mA}$ applied current at $\mathrm{pH} 3$ and $35^{\circ} \mathrm{C}$. A: Color removal. B: \% TOC decay as electrolysis time function.
Ion exclusion chromatograms of the solutions at 20-30 min exhibited peaks associated with carboxylic acids generated during the electrolysis, with retention times $\left(r_{t}\right)$ are: oxalic $\left(r_{t}=6.62\right)$, citric $\left(r_{t}=7.86\right)$, malic $\left(r_{t}=8.91\right)$ and oxamic $\left(r_{a}=9.6 \mathrm{~min}\right)$. Citric and malic acids could be formed from the oxidative cleavage of benzenic moiety. Oxamic acid could be produced from the oxidation of the azo, amine and amide groups present in both compounds. Oxalic and oxamic acids are ultimate carboxylic acids that are directly transformed into $\mathrm{CO}_{2}$. Fig. 5A and 5B evidence the accumulation of carboxylic acids during electrolysis of AV7 and RB5 solutions respectively during the EF treatment, which are rapidly removed to disappear in 60-70 min of electrolysis.
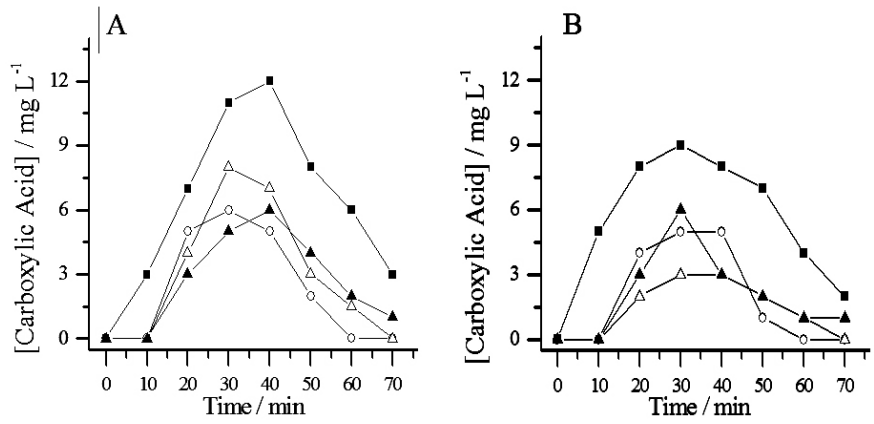

Figure 5. Evolution of ( $(-)$ oxalic, $(\Delta)$ oxamic, $(o)$ malic and (p) citric acids detected during the EF degradation of $250 \mathrm{mg} \mathrm{L}^{-1}$ of AV7 (A) and RB5 (B) solutions under the same experimental conditions of Fig. 4.

A comparison of color removal and TOC decay during the electrolysis evidences that the mineralization of the solutions occurs more slowly than decolorization, in agreement with the presence of the carboxylic acids as intermediates. Note that the maximum concentration of carboxylic acids occurs at time near to the induction time in Fig. 4B which confirm the hypothesis about the difference in plot A and B of Fig. 4 .

Clearly, this is observed in Fig.4-B, where after $30 \mathrm{~min}$ of electrolysis the color removed is near $80 \%$ and TOC decay only $10 \%$, still evidencing the presence of organic substances. This behavior can be accounted for considering the reaction between ${ }^{\bullet} \mathrm{OH}$ and $\mathrm{C}-\mathrm{N}-\mathrm{N}$ bond, which cause the solution to fade and generate colorless by-products at short times. Thus, in agreement with the mechanism proposed by other authors ${ }^{\square}$, the first step in the oxidation of AV7 and RB5 should be the cleavage of the azo group to form colorless intermediates (mainly carboxylic acids and small carbonyl species). Finally, the solutions achieve a pale yellow color and the TOC decay is greater than $40 \%$ at 70 min of electrolysis, confirming the conversion of dyes into $\mathrm{CO}_{2}$. The MCE is 81 and $74 \%$ for AV7 and RB5, respectively.

\section{Photo electro-Fenton process.}

When the electrochemical system is irradiated with UVA radiation, increases the decolorization of AV7 and RB5 with respect to EF method. As can be seen in Figure 6 for both dyes, the color removal is greater than $95 \%$ at only 30 minutes of electrolysis. The TOC decay is faster than in the EF process, without show an induction time as in Fig. 4-B. A possible reason could be the photodecarboxylation by UV light of Fe(III)-oxalate complexes (Eq.(4). Is well-known that those complexes cannot be destroyed by hydroxyl radicals ${ }^{38}$, but in the presence of UV radiation is favored the photolysis of $\mathrm{Fe}(\mathrm{III})$ complexes with carboxylic acids $\left(\mathrm{Fe}(\mathrm{OOCR})^{2+}\right)$ generated in this process, allowing reach almost the $100 \%$ of mineralization at 70 minutes.
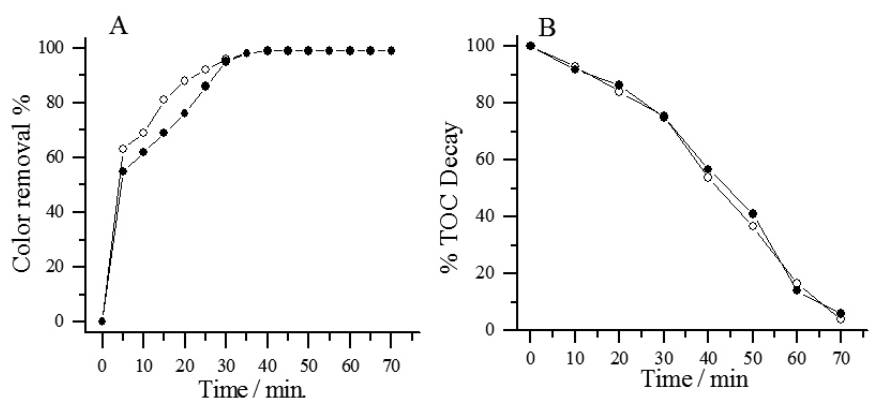

Figure 6. PEF process of $250 \mathrm{mg} \mathrm{L}^{-1} \mathrm{AV} 7(\circ)$ and RB5 (•) under $0.01 \mathrm{mM}$ $\mathrm{Fe}^{2+}, 250 \mathrm{~mA}$ applied current at $\mathrm{pH} 3$ and $35^{\circ} \mathrm{C}$. A: Color removal. B: \% TOC decay as electrolysis time function. 
In Table 1 are compared the characteristic parameters of both processes showing in PEF process the effectiveness of UVA irradiation in the mineralization of dyes with MCE of $97 \%$ for AV7 and 95\% for RB5 confirming that in the mineralization PEF process is more efficient than EF method. In the same sense, in the \%TOC decay-time plot a change in slope is observed at nearly 30 min evidencing again that there is just a step where the ${ }^{\bullet} \mathrm{OH}$ reacts firstly with the azo group to form intermediates which are quickly oxidized in successive steps. In agreement with other authors ${ }^{39,40}$, the use of radiation UVA at EF systems considerably increase the mineralization of organic pollutants since it favors the generation of homogeneous ${ }^{\bullet} \mathrm{OH}$ and the photodegradation of complexes of Fe(III) with organics.

Table 1. Comparison between different degradation processes used in this work. \% Color removal, \% TOC Decay and MCE were calculated using eq. 3, 4 and 5 , respectively. Apparent rate constant was calculated from integrated Eq. 13.

\begin{tabular}{|c|c|c|c|}
\hline \multicolumn{2}{|c|}{$\begin{array}{ll}\text { Method } & \text { Dye }\end{array}$} & AV7 & RB5 \\
\hline \multirow{4}{*}{$\begin{array}{l}\text { Electro- } \\
\text { Fenton }\end{array}$} & Color removal (\%) / $30 \mathrm{~min}$ & 89 & 82 \\
\hline & TOC Decay (\%) / 70 min & 87 & 68 \\
\hline & $\operatorname{MCE}(\%) / 70 \mathrm{~min}$ & 81 & 74 \\
\hline & Apparent rate constant $\times 10^{-3} / \mathrm{min}^{-1}$ & $63 \pm 0.8$ & $41 \mathrm{x} \pm 0.5$ \\
\hline \multirow{4}{*}{$\begin{array}{l}\text { Photo } \\
\text { Electro- } \\
\text { Fenton }\end{array}$} & Color removal (\%) / $30 \mathrm{~min}$ & 95 & 96 \\
\hline & TOC Decay (\%) / 70 min & 96 & 92 \\
\hline & $\operatorname{MCE}(\%) / 70 \mathrm{~min}$ & 97 & 95 \\
\hline & Apparent rate constant $\times 10^{-3} / \mathrm{min}^{-1}$ & $106 \pm 1.4$ & $98 \pm 1.1$ \\
\hline \multirow{3}{*}{ Fenton } & Color removal (\%) / $30 \mathrm{~min}$ & 43 & 37 \\
\hline & TOC Decay $(\%) / 70 \mathrm{~min}$ & 18 & 11 \\
\hline & Apparent rate constant $\times 10^{-3} / \mathrm{min}^{-1}$ & $12.3 \pm 0.7$ & $10.5 \pm 0.9$ \\
\hline \multirow{3}{*}{$\begin{array}{l}\text { Photo } \\
\text { Fenton }\end{array}$} & Color removal (\%)/ $30 \mathrm{~min}$ & 62 & 53 \\
\hline & TOC Decay $(\%) / 70 \mathrm{~min}$ & 26 & 20 \\
\hline & Apparent rate constant $\times 10^{-3} / \mathrm{min}^{-1}$ & $18.4 \pm 0.8$ & $20.0 \pm 0.8$ \\
\hline
\end{tabular}

Comparison with classic Fenton's reaction.

Different $\mathrm{H}_{2} \mathrm{O}_{2}$ concentration was used for studying the homogeneous degradation of dyes under the same experimental condition used in EF method. That is, $0.1 \mathrm{mM} \mathrm{Fe}^{2+}$, and $\mathrm{pH} 3$ at $35^{\circ} \mathrm{C}$. The Fenton process employs a mixture of $\mathrm{H}_{2} \mathrm{O}_{2}$ and $\mathrm{Fe}^{2+}$ under acidic $\mathrm{pH}$ conditions for the generation of ${ }^{\bullet} \mathrm{OH}$, which may reacts with organic molecules. In order to evaluate the effectiveness of the method compared to the Fenton traditional method, we proceeded to electrolyze each dye under the same experimental conditions, namely $250 \mathrm{mg}$ $\mathrm{L}^{-1}$ at $\mathrm{pH} 3$ and $35^{\circ} \mathrm{C}$.

Decolorization of both dyes solutions with $1.0 \mathrm{mM}$ of $\mathrm{H}_{2} \mathrm{O}_{2}$ (ten times greater than the $\mathrm{Fe}^{2+}$ concentration) in Fenton process does not exceed 50\% and TOC decay is approximately $20 \%$ at $60 \mathrm{~min}$ of electrolysis, showing that the mineralization is far from being complete.

When the solutions were irradiated by UVA, the decolorization and mineralization increased mildly as shown in Table 1.

Rate constant (k) determination.

Concentration decay curves of the dyes as a function of the electrolysis times were obtained by HPLC experiments were a peak with retention time $\left(\mathrm{r}_{\mathrm{t}}\right)$ of 4.4 min was observed for RB5 and $F_{t}-3.8$ min for VA7. For each dye, a decrease in the peak intensity with the electrolysis time was observed.

Degradation of organics by EF process follows a pseudo-first order reaction ${ }^{41}$ with a rate expression of dyes in reaction with ${ }^{\bullet} \mathrm{OH}$ (supposing the quasi-steady-state assumption of ${ }^{\bullet} \mathrm{OH}$ concentration) can be written as:

$$
\begin{aligned}
& \text { Dye }+\cdot \mathrm{OH} \rightarrow \text { Oxidation products } \\
& \frac{\mathrm{d}[\text { dye }]}{d t}=k_{\text {obs }}[\cdot \mathrm{OH}][\text { dye }]=k_{\text {app }}[\text { dye }]
\end{aligned}
$$

where $k_{\text {obs }}$ and $k_{\text {app }}$ are the intrinsic and apparent rate constants, respectively. The $k_{\text {app }}$ were evaluated from consumption of dyes under optimum electrolysis conditions and the results also are shown in Table 1 for each method used in this work and correspond to the slope of the integrated form of Eq. 13, this is by plotting $\operatorname{Ln}\left([\text { dye }]_{0} /[\right.$ dye $]$ ) against time.

As can be seen, the apparent rate constant values increase for both dyes with UVA radiation, in concordance with the efficiency of the process in the $\cdot \mathrm{OH}$ generation.

In the case of AV7 the apparent rate constant increases 1.7 times by PEF respect to the value obtained in EF, whereas for RB5 the increase was 2.4 times with UVA radiation. In the case of experiments of Fenton and Photo Fenton, the $k_{\text {app }}$ values were 3.5 times lower than electrochemical procedures for both dyes. Moreover, by EF and PEF methods we obtained a complete mineralization and decolorization of solutions while by no-electrochemical methods a partial decolorization and mineralization was observed (Table 1).

\section{CONCLUSIONS}

Mineralization and decolorization of Acid Violet 7 and Reactive Black 5 by electro-Fenton and Photo electro-Fenton using a vitreous carbon electrode cathode and an anode of steel mesh was almost total in short times. The Photo electro-Fenton process was more efficient, both in decolorization and mineralization of solutions, with respect to electro-Fenton method, due to the generation of more amounts of $\bullet \mathrm{OH}$ induced from reaction (Eq. 3) by the UVA irradiation and by the photodecomposition of Fe(III) complexes with byproducts allowed the almost total mineralization of both dye solutions. The PEF treatment showed more than $90 \%$ removed of TOC of the dye solutions at $70 \mathrm{~min}$.

Finally, in the degradation process we want to emphasize that the decolorization of the solutions giving yellow pale color containing organic intermediates (carboxylic acids) that finally are completely transformed to carbon dioxide. Secondly, in the studied process, EF and PEF is not need to added hydrogen peroxide because this is generated in the cathode, and a small amount of catalyst $\mathrm{Fe}^{2+}$ is necessary. Finally the complete mineralization of studied dyes occurs in short times with high efficient currents.

\section{ACKNOWLEDGEMENTS}

DICYT-USACh and CONICYT- Chile, under postdoctoral grant PDA-03 Inserción a la Academia.

\section{REFERENCES}

1.- Ministerio de Obras Públicas. Decreto 609: Establece norma de emisión para la regulación de contaminantes asociados a las descargas de residuos industriales líquidos a sistema de alcantarillados. Chile. (1998).

2.- K. P. Sharma, S. Sharma, K. P. Singh, S. Kumar, R. Grover, P. K. Sharma. Chemosphere 69, 48 (2007).

3.- M. S. Khehra, H. S. Saini, D. K. Sharma, B. S. Chadha, S. S. Shimni. Dyes \& Pigments 70, 1 (2006).

4.- C L. Yang, J. McGarrahan. J Hazard Mat B 127, 40 (2005).

5.- I. A. Sengil, M. Özacar. J Hazard Mat 161, 1369 (2009).

6.- I. Sirés, P. L. Cabot, F. Centellas, J. A. Garrido, R. M. Rodríguez, C. Arias, E. Brillas. Electrochim Acta 52, 75 (2006)

7.- M. Panizza, A. Kapalka, Ch. Comninellis. Electrochim Acta 53, 2289 (2008).

8.- A. Serra, X. Domenech, C. Arias, E. Brillas, J. Peral. Appl Catalysis B: Environ 89, 12 (2009).

9.- M. Panizza, G. Cerisola. Water Res 43, 339 (2009).

10.- W. P Ting, M.C. Lu, Y. H. Huang. J Hazard Mat 156, 421 (2008).

11.- F. Paschoal, M. A. Anderson., M. Valnice, B. Zanoni. Desalination 249, 1350 (2009).

12.- C. A. Martínez-Huitle, E. Brillas. Appl Catalysis B: Environ 87, 105 (2009).

13.- C. A. Martínez-Huitle, S. Ferro. Chem. Soc. Rev. 35, 1324 (2006).

14.- P. Caziñares, R. Paz, C. Sáez, M. A. Rodrigo. J Environ Management 90, $410(2009)$.

15.- J. Virkutyte, V. Jegatheesan. Biores Technol 100, 283 (2009).

16.- S. Figueroa, L. Vázquez, A. Alvarez-Gallegos. Water Res 43, 283 (2009).

17.- S. P. Sun, C. J. Li, J. H. Sun, S. H. Shi, M. H. Fan, Q. Zhou. J Hazard Mat. $161,1052(2009)$

18.- Y. Sun, J. Pignatello. J. Environ Sci Technol 27, 304 (1993).

19.- A. Alvarez-Gallegos, D. Pletcher. Electrochim Acta 44, 853 (1998).

20.- M. Sudoh, M. Yamamamoto, T. Kawamoto, K. Okajima, N. Yamada. J Chem Eng Jpn 34, 884 (2001).

21.- Z. Quiang, J.H. Chang, C. P. Haung. Water Res 36, 85 (2002).

22.- M. Panizza, G. Cerisola. Electrochim Acta. 54, 876 (2008).

23.- G. R. Agladze, G. S. Tsurtsumia, B. I. Jung, J. Kim, G. Gorelishvili. J Appl Electrochem 37, 375 (2007).

24.- E. Brillas, B. Boyle, I. Sires, J. A. Garrido, R. M. Rodriguez, C. Arias, P. 
L. Cabot, Ch. Comninellis. Electrochim Acta 49, 4487 (2004).

25.- E. Brillas, E. Mur, J. Casado. J Electrochem Soc 143, L49 (1996).

26.- W-P Ting, Ming-Chun Lu, Yao-Hui Huang. J. Hazard. Materials. 156 (2008) 421-427.

27.- R. Salazar, S. Garcia-Segura, M.S. Ureta-Zañartu, E. Brillas. Electrochim. Acta 56, 6371 (2011).

28.- M.S Lucas, J.A Per. Dyes and Pigments 71, 236 ( 2006)

29.- N. K. Kiliç, J. L. Nielsen, M. Yüce, G. Dönmez. Chemosphere, 67, 826 (2007).

30.- I. Muthuvel, M. Swaminathan. Catalysis Comm, 8, 981 (2007).

31.- C. Tang,V.Chen. Water Research 38, 2775 (2004).

32.- I.A. Alaton, A.Balcioglu. J. of Photochem and Photobid A: Chemistry 141, 247 (2001).

33.- B. Boye, M. M. Dieng, E. Brillas. Environ Sci Technol 36, 3030 (2002).
34.- Ch. Comninellis, G. Chen. Electrochemistry for the Environment. 1st ed. New York. Springer. Ch. 1, pp.1-23 (2009).

35.- A. Ozcan, Y. Sahin, A.Koparal, M. A. Oturan. App. Cat. B: Environmental 89620 (2009).

36.- N. Oturan, M. Panizza, M. A. Oturan. J Phis Chem A 113, 10988 (2009).

37.- Z. Shen, J. Yang, X. Hu, Y. Lei, X. Ji, J. Jia, W. Wang. Environ Sci Technol 39, 1819 (2005).

38.- Y. Zuo, J. Hoigné, Environ. Sci. Technol. 26, 1014 (1992).

39.- H. Kusic, N. Koprivanac, L. Srsan. J Photochem Photobiol A: Chem 181, 195 (2006).

40.- M. Skoumal, C. Arias, P. L. Cabot, F. Centellas, J. A. Garrido, R. M. Rodríguez, E. Brillas. Chemosphere 71, 1718 (2008).

41.- B. Balcia, N. Oturan, R. Cherrierb, M. A. Oturan. Water Res 43, 1924 (2009). 